\title{
LITERATURE
}

$\infty$

\author{
Roman Vasylenko \\ Maria Curie-SkŁodowska University (UMCS) in Lublin \\ ROMAN.VASYLENKO44@GMAIL.COM
}

\section{James Joyce's Play with Dramatic Conventions in Ulysses (1922): Episode 15 "Circe”}

\begin{abstract}
This essay focuses on the fifteenth episode of James Joyce's Ulysses (1922), "Circe", which is written in the form of a drama script. My claim is that in "Circe" Joyce subverts the traditional Western view of drama, established by Aristotle in Poetics (c. 335 BCE), particularly with respect to the principles of imitation, the plot structure, the process of interpretation, and the role of dramatis personae. The focal point of the analysis, also inspired by the ancient critical text, will be Joyce's vision of the categories of time and space and their implementation in "Circe".
\end{abstract}

Key words: James Joyce, Ulysses, dramatic conventions, play, modernism, time, space.

If any of the episodes may be called central in Ulysses, it would definitely be "Circe". First of all, it is the longest episode in the novel. Secondly, only in this episode does Bloom (the archetypical father, Ulysses) directly meet Stephen (the archetypical son, Telemachus). Thirdly, "Circe" can be regarded as a summary of the novel since in the episode most of the novel's key motifs and themes are recapped: the father and son bond, religion, nationalism, patriotism, the relationship between the Irish and the British, infidelity, love, social exclusion, artistic struggle, loneliness, and, finally, life and death. Most of the characters that appeared throughout the day in the previous fourteen episodes reappear simultaneously in "Circe". Furthermore, even memories, thoughts, expectations, desires, and fears, in a word, the mental processes that took place in the course of the day, acquire a physical materialization in this episode. It would appear that Joyce chose the drama script as a stylistic form of the episode in order to underscore its intensity. In the first part of the article, I will introduce the basic principles of classical drama and their consequent subversion by Joyce while in the second part 
I will concentrate upon the juxtaposition of the classical unities of time and space and the dimensions of time and space in "Circe".

The fifteenth episode of Ulysses (1922), "Circe" is a play in two senses of this word. First of all, the form of "Circe" is different from all the other chapters of the novel: "[t]he whole episode is typographically written as a play script whose function is to resemble the printed text of a play, complete with stage instructions in italics" (Mahon 2009, 121). As Fargnoli notes, this dramatic technique "indicates a radical departure from the prose style of the rest of the novel and indeed from most conventional narratives" $(2006,201)$. Secondly, it is a text in which Joyce plays with the classical dramatic conventions and, consequently, with the readers' expectations. Regarding Aristotle's Poetics (c. 335 BCE) as the key theoretical text of the Western dramatic history, we can say that Joyce subverts its fundamental principles.

First of all, he rejects Aristotle's mimesis or the idea that drama's main function is to imitate action. Notably, in "Circe", although the setting (the episode set in Dublin's red-light district), "stage directions, and dramatis personae are clearly indicated, they rarely give one a fully formed sense of the direction of action" (Fargnoli 2006, 198). Therefore, sometimes it is quite problematic for the reader to define which actions are "real" (i.e. mimetic) and which can be regarded as hallucinations. "Thus, the episode repeatedly foregrounds an ambiguity that will challenge any interpretation, and ultimately the reader's procedure for deriving meaning is shown to be a deeply subjective process" (Fargnoli 2006, 198). For example, Cissy Caffrey and Edy Boardman, who are portrayed as "two innocent young girls" in the Nausicaa episode (four hours before "Circe's" action takes place) "reappear in this episode ["Circe"] as prostitutes" (Fargnoli 2006, 199).

Secondly, Joyce plays with Aristotle's notion of the plot. He undermines the traditional structure of drama which, consists of an exposition, rising action, climax, falling action and, finally, resolution. In fact, there is no beginning, middle, or ending in "Circe". Instead, we are offered a number of supernatural events that, at first glance, seem to be hardly connected. In the context of the entire novel, "Circe" starts after the fourteenth episode ("Oxen of the Sun") and ends before the sixteenth episode ("Eumaeus"), hence the problems and conflicts of "Circe" are already known to the reader before the episode's beginning, and at the end no final resolution is offered. Even when one approaches "Circe" as a separate text, independent of the rest of the novel, its structure still looks disjointed and incoherent (Wales 1992, 110).

While Aristotle states that drama should tell "the one complete story" (Stenudd), Joyce offers the opposite. "Circe" is a "drama which consists of several mini-plays"1, varying in size and importance, which evoke different problems and are arranged together by the unifying consciousness of two main characters: Bloom and Stephen (Khorouji 2013, 873). Importantly, all of these mini-plays have irregular structure and

This and all further translations from Russian are my own. 
offer no resolution of a conflict (such as the father and son conflict), containing instead a series of climaxes which make the text difficult to follow and understand.

Thirdly, the traditional Aristotelian choice of dramatis personae is also negated by Joyce. Usually, the reader expects a protagonist who is an individual of a social status higher than that of the audience (Stenudd 2006), marked wit, goodness, consistency, and coherence (Stenudd 2006). In contrast, Bloom and Stephen are average members of the middle class, and Bloom is frequently recognized as an everyman (Clifford 2015, 2). Joyce's usage of the supernatural seems to make the appearance of the main characters, Bloom and Stephen, even more inconsistent with the classical dramatic tradition through the introduction of grotesquery and the ludicrous. A case in point is, for instance, Bloom's conduct when asked to perform a miracle:

Bloom walks on a net, covers his left eye with his left ear, passes through several walls, climbs Nelson's Pillar, hangs from the ledge by his eyelids, eats twelve dozen oysters (shells included), heals several sufferers from king's evil, contracts his face so as to resemble many historical personages, lord Beaconsfield, lord Byron, Wat Tyler, Moses of Egypt, Moses Maimonides, Moses Mendelssohn, Henry Irving, Rip Van Winkle, Rossuth, Jean Jacques Rousseau, Baron Leopold Rothschild, Robinson Crusoe, Sherlock Holmes, Pasteur, turns each foot simultaneously in different directions, bids the tide turn back, eclipses the sun by extending his little finger (Joyce 1992, 615).

"Circe" also departs from the classical dramatic conventions as the reader is already familiar with the main characters before reading the text of the play. As the reader knows the precise background and the intimate thoughts of the protagonists, there is no need for the author to present the characters and reveal their intentions. In other words, due to the reader's familiarity with the dramatis personae, an exposition is redundant.

Furthermore, the choice of secondary characters seems to introduce the comical into the play which is otherwise closer to a tragedy, thus breaking with the notion of decorum. Some of the dramatis personae do not have any particular function which would influence the plot, existing simply for their own sake, or to reinforce the eerie atmosphere in the episode. For example, there are characters such as "The Calls", "The Answers", "The Gaffer", "The Gasjet", etc. An even more peculiar effect is created by the fact that "all manner of inanimate objects begin to speak, just as he [Bloom] observed they did in 'Aeolus' bells say 'Haltyaltyaltyall' and tram warning gongs say 'Gong Bang Bang Bla Bak Blud Bugg Bloo’ etc.” (Mahon 2009, 121). Consequently, these phenomena, verging on the absurd and the grotesque, only enhance the effect of the supernatural in the episode.

Fourthly, Joyce inverts the conventional Aristotelian notion of dramatic diction. Traditionally, the language in a tragedy is expected to be purposeful, logical, and consistent, while its main function is to convey a meaningful message (Stenudd 2006). In contrast, the language in "Circe" is best described by such terms as " dis-integration"; 
'dis-location'; 'disorder': the prefix dis- is hard to avoid in any appreciation of Joyce's syntax" (Wales 1992, 110). This quality of "Circe" is well illustrated by Stephen's hallucination in which the protagonist is spinning in what Wales (1992) calls, "a great phantasmagorical climax, in which audible and visual effects, puzzling neologisms, and unregulated syntax are intertwined inextricably":

Groangrousegurgling Toft's cumbersome whirligig turns slowly the room right roundabout the room...

With clang tinkle boomhammer tallyho horn blower blue green yellow flashes. Toft's cumbersome turns with hobbyhorse riders from gilded snakes dangled, bowels fandango leaping spurn soil foot and fall again...

Closeclutched swift swifter with glareblareflare scudding they scotlootshoot lumbering by. Baraabum!... (15.4112-31) (109).

Let us now explain how the ambiguous relationship between "reality" and hallucination is created in the "Circe" episode. "Real" means the events that could actually happen and exist (i.e. mimetic action), in contrast to the hallucinations which appear in the mind of the main characters. The Russian translator of Ulysses (1922), Sergei Khorouji (2013), poses a valid question: What is the reason that the main characters suddenly began to hallucinate (872)? At first glance, the answer seems to be quite simple. Since the episode takes place at midnight, we may presume Bloom and Stephen are tired and may be under the influence of alcohol. In fact, both of these suggestions prove false (Khorouji 2013, 872) as, unlike Stephen, Bloom is definitely sober and, secondly, Bloom simply cannot be aware of some people and events that occur during his hallucinations (Nabokov 2002, 350).

Nabokov (2002) suggests that a particular detail of the episode begins to live its own life in a hallucination, independent of reality (352). As Mahon (2009) puts it, "every word and gesture performed by a character in the text is potentially powerful enough to transform and exaggerate the appearance of the character" and the events, thus move the plot forward. (121). Let us consider an example. When Bloom is frustrated and disorientated in the gloomy atmosphere of the night-town and afraid that somebody will steal his wallet, instantaneously, a passing dog converts into the caricature of a stereotypical Jew, Bloom's father, Rudolph, who scolds him for spending time out and warns that bad company will cause his bankruptcy. When Bloom wants to object to the reproach, his father claims sarcastically that it would be "nice spectacles" (Joyce 1992, 569) to Bloom's mother. The phrase about Bloom's mother immediately evokes her appearance. The sense of guilt for being reckless towards his mother evokes the appearance of another woman and provokes more guilt: his wife Molly materializes, dressed as a stereotypical Oriental princess (her appearance in Bloom's last dream), and accompanied by a camel. She commands Bloom to address her as "Mrs. Marion", which is a sarcastic hint of her adultery with her impresario, Blazes Boylan. Experiencing pangs of conscience over his inability to satisfy his wife, Bloom wants 
to please her and looks for the lotion which he promised to buy. Finding only a lemon soap instead, he apologizes and promises to mend the error the next day. At once, a new day begins with the rising of a singing lemon soap instead of the sun. Thus, in "Circe" Joyce demonstrates "the power of the words" where even a single word can change the direction of the action (Mahon 2009, 122).

Although the main characters, Bloom and Stephen, hallucinate extensively, they do not realize it. At the very beginning of the episode, Bloom warns the motorman of a sandstrewer by "raising a policeman's whitegloved hand" (Joyce 1992, 567), whereas, as Mahon (2009) observes, "up till now there has been no mention of Bloom's owning a pair of gloves, never mind white ones" (121). A few moments later, on the appearance of a "sinister figure under a wideleaved sombrero" (Joyce 1992, 567-568), Bloom speaks Spanish. Both of these strange episodes remain unnoticed by Bloom. This leads Mahon to draw the conclusion that the text attempts to show a discrepancy between its narrative frame and the characters it describes (Mahon 2009, 122).

Returning to "Circe's" experimental approach to literary traditions, it must be stated that the most interesting experiments are conducted by Joyce with regard to the classical unities: the unity of time, the unity of space, and the unity of action. While Joyce's violation of the unity of action has already been briefly discussed, I will move on to focus on the unities of time and space. Although these categories are usually regarded jointly, they will be separated and examined individually for the sake of this analysis.

According to Aristotle, the action of drama should cover no longer than twenty-four hours (Stenudd 2006). Formally, Joyce follows this rule: the episode lasts for one hour (00:00-01:00), yet, in fact, within this hour the author introduces different layers of cultural, mythical and historical time, "compress[ing], skew[ing] and lump[ing] everything together" (Lowe 2009, 477).

According to Kern (2003), Joyce disapproved of the generally accepted vision of time defined by Newton, as an "[a]bsolute, true, and mathematical" entity, which moves forward independently from anything external (11). Instead, being under the influence of Einstein's theory of relativity and Bergson's theory of dureé, Joyce distinguished between "public and private time" (Kern 2003, 33). As stated by Kern (2003), "public time", being uniform and homogeneous, suggests a collective perception of time as experienced by the group of people, while "private time", having heterogenous and fluid nature, refers to the individual's sense of time, meaning that it is relative and depends on an individual (64).

"Circe", therefore, is a practical manifestation of Joyce's ideas concerning time. Specifically, the temporal division in the episode relies on the introduction of the public, or narrative, time and private time of the main characters, expressed in a hallucination (Lowe 2009, 477). As a result, in Kern's words (2003), "[a]lthough the narrative time of the segment lasts for a few seconds, the private time of the segment extends over a large duration and shifts erratically in it" (28).

To illustrate, during the flirty conversation with Zoe Higgins (one of the prostitutes) Bloom states that smoking is bad. She sarcastically proposes that Bloom elaborates 
on this statement and "make[s] a speech out of it" (Joyce 1992, 601). This is immediately followed by a forty-page hallucination in which Bloom, transformed into an ambitious political agitator and dressed in "black gansy with red floating tie" (Joyce 1992, 601), makes a pompous political speech on Walter Raleigh, tobacco, and the public life. As the hallucination develops, Bloom makes an impressive political career, becoming a leader of the military, political (both British and Irish) and religious powers of Dublin and Ireland. Marching through the triumphal arches, the procession of the highest members of the Irish society led by John Parnell (brother of the Irish Nationalist politician, Stewart Parnell) praises Bloom, mounted on the white horse. The Bishop of Down and Connor introduces him as "undoubted emperor president and king chairman, the most serene and potent and very puissant ruler of this realm. God save Leopold the First!" (Joyce 1992, 604). Later on, we see "Bloom the generous" (Blamires 1976, 181), who bestows gifts on the crowd (of which Bloom was dreaming himself during the day) (Kern 2003, 181), such as "expensive Henry Clay cigars" (Joyce 1992, 607), "readymade suits" (607), and "dairyfed pork sausages" (607). After taking the role of an entertainer, performing "juggler's tricks" (608), and drawing "red, orange, yellow, green, blue, indigo and violet silk handkerchiefs from his mouth" (608), Bloom is characterized as "a new example of a womanly man" (614) and gives birth to eight male children. Finally, the Fire Brigade sets Bloom on fire and "Bloom-Christ in a seamless garment marked I. H. S., suffers his crucifixion" (183). As Blamires (1976) notices, "in a brief return to actuality, the reader hears the voice of Zoe saying, 'Talk away till you're black in the face', which follows immediately on the talk of smoking" (184). This means that this long series of hallucinations lasts only for a few seconds in "public time". As Kern (2003) concludes, in "Circe":

Joyce created a dramatic interruption in the forward movement of narrative time. In those few seconds of his [Bloom's] time [the pause between the two sentences], the reader is led through a long digression that involves dozens of characters and that covers a period of time far exceeding the few seconds that elapsed public time would have allowed (31).

According to Khorouji (2013), Joyce was highly critical of the idea of history as a single development, regular process, and linear movement towards the future (Khorouji 2013, 746). Instead, he perceived history as an eternal, complex cyclical construction in which the events recur in similar patterns (Khorouji 2013, 746). Thus, in "Circe" Joyce realizes his idea of temporal cyclicity by employing different layers of time: historical, mythological, cultural, and religious.

Firstly, the episode contains many characters that are part of the political and national history of Ireland, such as John Howard Parnell, Timothy Harrington (Lord Mayor of Dublin), etc. Yet the application of the historical time is most evident in the scene when Stephen has a quarrel over an Irish-British relationship with two British soldiers, Privates Carr and Compton. The drunk protagonist continues to mock the soldiers in a highly arrogant manner. It is important to note that the reader not only hears 
the exchange through the dialogue, but also sees the attitudes of the speakers in an absurdly exaggerated form, as if filtered through the mind of Stephen (Blamires, 203). Thus, when the soldiers' irrational aggressiveness asserts itself, Lord Tennyson appears in Union Jack blazer and cricket flannels to proclaim, "Theirs not to reason why" (Blamires 1976, 203). Later on, Stephen, indicating his disobedience to any absolute power, says metaphorically "I must kill the priest and the king" (Joyce 1992, 688). Private Carr threatens Stephen and there begins the hallucination in which "King Edward VII makes his appearance complete with masonic regalia and plasterer's bucket, and mouthing hackneyed slogans" (Blamires 1976, 204). The presence of such historical figures as King Edward VII and Lord Tennyson in an episode that takes place on $16^{\text {th }}$ June 1904 bolsters the effect of the non-linearity of time.

Secondly, the main characters act not only as Bloom and Stephen, but, through intertextual references, also as past literary, cultural, and mythological characters. To state the obvious, the title of the novel is Ulysses and the title of the episode is "Circe", which refers the reader to Homer's Odyssey, making Leopold Bloom an ancient hero - Ulysses; the owner of the brothel, Bella Cohen - the goddess of magic Circe, and Bloom's adventures in the brothel - Circe's magical transformation of the main characters into swine. It has already been mentioned that Bloom also adopts the role of Jesus Christ and experiences a crucifixion, yet he is not the only one in the episode who performs the role of the Savior. During the personal conflict between Stephen and Private Carr, "the flavor of epic conflict [...] even of cosmic disaster is added to the crisis moment. There appears the epic cataclysm with crucifixion parallels: the sun is darkened, the earth trembles, the dead arise and appear to many, and, finally, the Black Mass is celebrated" (Blamires 1976, 205). As Blamires also notices, "there is another explicit parallel with the Crucifixion at this point for when Lynch forsakes him, Stephen identifies him as Judas, underlying the correspondences between himself and Christ" (Blamires, 206). Stephen says, "Exit Judas. Et lacquer se suspendit" (Joyce 1992, 696). His usage of Latin, the language of the mass, usually employed to create a solemn atmosphere, is contrasted with the embarrassing context - the drunk Stephen is abandoned by his friend in Dublin's red-light district. Performing Jesus Christ, Stephen experiences his crucifixion when Private Carr knocks him out, though "“no bones are broken' (Christ's condition on the Cross)" (Blamires 1976, 206). In another reference to the Bible, Stephen is said to "touch Lucifer's fall through the sin of pride" (202). During the hallucination, Stephen is talking to his mother, a symbol of an "absolute possessiveness" (202) and, when she asks the son to repent, he cries "Non Serviam" (Joyce 1992, 683). "In the agony of death she prays for the divine mercy on him, and he lifts his ashplant and smashes the chandelier, crying Nothung," (Blamires, 202) in reference to Wagner's opera and to the Norse mythological hero Siegfried.

Due to all the chaotic intermingling of the various references (historical, mythological, and religious), and despite the magnitude of the referenced material (parallels with Jesus, Homer, and Shakespeare), the overall atmosphere in the episode seems to be more farcical than serious. For example, during one of the scenes Stephen is associ- 
ated with Hamlet, Lucifer and an epic hero of Norse mythology Siegfried, but still he is a drunken, broken, and fruitless poet in a Dublin brothel.

Another technique serving to disrupt the linearity of time employed in "Circe" is simultaneity. While in the earlier episodes - "Wandering Rocks" and "Nausicaa" Joyce used simultaneity "to extend the present spatially", in "Circe" he saturates the episode with the elements of the character's past and future in order to convey the sense of temporal simultaneity (Kern 2003, 81). Kern calls this effect the "affirmation of the now" (86), and praises Joyce for compressing memories and expectations of Bloom and Stephen with the different cultural and religious events into a single hour in Dublin's brothel.

The fact that during the episode the reader sees Bloom as a man of different ages may be treated as a striking example of simultaneity. On the day when the events occur in the novel (16th June) Bloom is thirty-eight years old, yet during the period of "Circe", when he enters the Nighttown at 00:00 and leaves at 01:00, his age and, consequently, his appearance change erratically.

At the beginning of the episode, on his way to the brothel Bloom meets Mrs. Breen, a woman with whom he was involved in his youth. At first, Mrs. Breen is cold to Bloom and accuses him of visiting the red-light district, but gradually the protagonist recalls the kindness of their relationship, and Mrs. Breen changes her attitude towards him. She softens and transforms into "Josie Powell [her maiden name] [...] prettiest deb in Dublin" (Joyce 1992, 574). They remember "Old Christmas night" (574), and Bloom becomes "[s]quire of dames" and "the lion of the night" (574) dressed "in dinner jacket $[\ldots]$ black bow and mother-of-pearl studs" (574), giving a toast with a glass of champagne. The second time when Bloom changes his age is during the scene when Zoe is flirting with him. She playfully calls him "Babby" (619) and, instantaneously, Bloom performs one of the shortest and strangest metamorphoses in the text - for a few seconds he becomes a toddler in his appearance and language:

BLOOM (In babylinen and pelisse, bigheaded, with a caul of dark hair, fixes big eyes on her fluid slip and counts its bronze buckles with a chubby finger, his moist tongue tolling and lisping.) One two tlee: tlee tlwo tlone. (Joyce 1992, 619)

The third transformation occurs during the hallucination in which Bello humiliates Bloom by calling him a cuckold. The man then transforms into an old, weary tramp with a "haggard bony bearded face" (653). His daughter Milly also notices this metamorphosis "My! It’s Papi! But. O Papli, how old you've grown!" (653).

Another vivid example of simultaneity is the co-presence of three different aspects of Bloom's personality. During the hallucination in the brothel, Bloom's Grandfather Lipoti Virag "chutes down through the chimneyflue" (Joyce, 1992 628). According to Blamires (1976), he represents the "commercial, scientific" part of Bloom's character because he helps his grandson to choose the prostitute by applying the medical and materialistic analysis (187). A few moments later, another element of Bloom's 
character is embodied: "Henry the romantic, mysterious lover with Saviour's face" (Blamires 1976, 189) - appears at the center of the room, whereas Henry Flower is the pen name under which Bloom writes the letter with sexual innuendos in the earlier episode. Blamires (1976) comments on the juxtaposition of the avatars as follows: "Then the three personae of the Bloom trinity are held for a moment together simultaneously in a single picture as Bloom the knowledgeable (Virag) stares at the lamp, Bloom the grave studies Zoe's neck, and Bloom the gallant (Henry) turns to the piano" (189).

In "Circe" Joyce also expresses his ideas concerning space, distorting both the Aristotelian notion of the unity of space in drama and the Newtonian understanding of the concept. According to Aristotle, a play ought to occur in a single physical location; a stage should not depict more than one place, and should not try to compress geography (Stenudd 2006). Newton, in turn, described space as "absolute" and "always similar and immutable" (Kern 2003, 132).

In contrast to Newton, Einstein postulated that space is not homogenous and absolute; it depends not on distance, but on velocity, the perspective, and the measurement applied, consequently, it is heterogeneous (Kern 2003, 136). To sum up, Einstein believed that "there is an infinite number of spaces, which are in motion with respect to each other" (qtd. in Kern 2003, 136). This sentence may be treated as an apt characterization of the representation of space in "Circe". Although the episode is written as a play script, which implies that the setting is formally restricted to a stage, "Circe" contains several interconnected spaces.

Joyce's play with the readers' expectations and the classical unity of space starts with the fact that although "Circe" is set in the Nighttown district including Mabbot, Talbot, and Tyrone streets of Dublin, the mimetic space is enriched by the additional locations evoked during hallucinations. To clarify: during an hour in Dublin's red-light district Bloom witnesses, "Beside mirage of datepalms" (Joyce 1922, 570), his wife Molly is in an exotic Turkish costume with a camel that plucks a fruit from a mango tree; he also sees gazelles feeding and leaping on the mountains next to the lakes, and, later on, talks to the nymph under a waterfall:

\author{
The sound of a waterfall is heard in bright cascade.) \\ THE WATERFALL \\ Poulaphouca Poulaphouca \\ Poulaphouca Poulaphouca (Joyce 1922, 658).
}

The amalgamation of the various locations from far regions of the world complicates the setting significantly.

Joyce's fascination with the cinema and with Cubism may be seen as the reason behind his employment of a heterogeneous space (Kern 2003, 138). Cubists were disappointed with the fact that, traditionally, painting could not convey the sense of motion and was constrained to representing an object from a single perspective (Kern 2003, 122). Instead, Cubists sought a way to change the rules and found them in introducing 
"a truly heterogeneous space in a single canvas with multiple perspectives of the same object" (Kern 2003, 141). The cinematography, in turn, developed the multiplication of perspectives by introducing the technique of editing and montage, "which made it possible to shift quickly between points of view and break up spatial coherence even further" (Kern 2003, 143). Similarly, Joyce rejects the predominance of one setting in literature. Kern (2003) concludes:

Thus the two most innovative novelists of the period [Proust and Joyce] transformed the stage of modern literature from a series of fixed settings in a homogenous space into a multitude of qualitatively different spaces that varied with the shifting moods and perspectives of human consciousnesses (149).

It must be said, however, that although Joyce constantly changes settings in "Circe", he does not do so for the sake of change itself. In other words, it is not an illogical and meaningless action; conversely, the setting adapts to the mood of the main characters and reflects their mental state. For instance, in the brothel, one of the prostitutes, Florry, starts a conversation on doomsday. When "the pressboys announce the safe arrival of Anti-Christ" (Blamires, 186), Florry secretly crosses herself and declares "the end of the world" (Joyce 1992, 624), while the gramophone, through the fog, blares "Jerusalem, Open your gates and sing Hosanna..." (624). Stephen's mind is full of associations with the apocalypse; therefore, the surrounding space reflects his state of mind and takes an appropriate form. As he succumbs to the eschatological thoughts, the end of the world immediately materializes:

(A rocket rushes up the sky and bursts. A white star falls from it, proclaiming the consummation of all things and second coming of Elijah. Along an infinite invisible tight-rope taut from zenith to nadir the End of the World, a two headed octopus in gillies kilts, busby and tartan filibegs, whirls through the murk, head over heels, in the fob of the Three Lugs of Man.) (624)

Joyce, once again following the Cubists, increased the creative function of space (Kern 2003, 154): while, traditionally it served as passive background defined as "inert void in which objects existed" (152), the author gives it more a "dynamic and active role" (154), constantly modifying space to reflect the main character's emotional states. Another example of the connections between the character and space is the scene in which Bloom flirts with Zoe. "He is no longer an outsider", he is admired, appreciated and, therefore, confident (Blamires 1976, 179). Space reflects his confidence and overall admiration, and a grand parade in his honor materializes:

Prolonged applause. Venetian masts, maypoles and festal arches spring up. A streamer bearing the legends Cead Mille Failte and Mah Ttob Melek Israel spans the street. All the windows are thronged with sightseers, chiefly ladies. Along the route the regiments of the royal Dublin Fusiliers, the Kings Own Scottish Boraerers, the Cameron Highlanders and the Welsh 
Fusiliers, standing to attention, keep back the crowd. Boys from High school are perched on the lampposts, telegraph poles, windowsills, cornices, gutters, chimneypots, railings, rainspouts, whistling and cheering. The pillar of the cloud appears. A fife and drum band is heard in the distance playing the Kol Nidre (Joyce 1992, 602).

Finally, Joyce, through Stephen, destroys the categories of time and space. The scene in which the rotten dead body of Stephen's mother appears and tries to evoke religious feelings is a culmination of his artistic independence and rebellion against authority, "history, time [and space] and guilt" (Kern 2003, 56). In this vivid climax Stephen takes the ashplant and smashes the chandelier, and at this action "[t]ime's livid final flame leaps and, in the following darkness, ruin of all space, shattered glass and toppling masonry" (Joyce 1992, 683). Stephen Kern (2003) comments on this scene as follows:

He smashes the light to obscure the image of his mother and put out the fire of his guilt. Stephen has stopped time in order to become an artist. The present is the only reality, especially for the artist [...] An effort must be made to hold the present because it is always slipping away, always threatening to have its uniqueness swamped by the old patterns of the past (56).

To sum up, in "Circe" Joyce's experimentation with different styles in the different episodes of Ulysses (1922), take the form of experimentation with classical dramatic conventions as postulated by Aristotle in Poetics (c. 335 BCE). Namely, Joyce subverts the idea of mimesis, undermines the traditional plot structure, and redefines the image of the protagonist. Yet, the most radical subversion is performed with regard to the classical unities of action, time and space. While Aristotle claimed that drama should tell a complete story in "one period of the sun" (Stenudd), Joyce breaks down the linearity of time and narrative sequence by introducing and intertwining different layers of time. Since as it was noted earlier, "Circe" may be regarded as a dense summary of the novel, in order to accommodate a variety of characters and events in one hour (00:00-00:01), Joyce stretches time, showing its "fluid and heterogonous nature" (Kern, 26). Even more evidently, the author perverts the classical unity of space. In contrast to Aristotle, who claimed that the play should take place in a single physical space, in "Circe" Joyce introduces different heterogeneous spaces, which switch erratically from one dimension to another. Following the Cubists and the pioneers of cinematography, Joyce tries to increase the creative role of space, reflecting the changing moods of the main character in an exaggerated way. 
Pobrane z czasopisma New Horizons in English Studies http://newhorizons.umcs.pl Data: 26/04/2023 17:16:25

James Joyce's Play with Dramatic Conventions in Ulysses (1922): Episode 15 “Circe” 101

\section{References}

Blamires, Harry. 1976. The Bloomsday Book: A guide through Joyce's Ulysses. London: Methuen.

Clifford, Jack. 2017. "The Amazing Leopold the Bloom The Everyman." Wordpress.com. https://johnkackclifford.files.wordpress.com/2015/02/leopold_bloom_character_study.pdf.

Fargnoli, Nicholas and Michael Patrick Gillespie. 2006. Critical Companion to James Joyce: A Literary Reference to His Life and Work. New York: Fact on File.

Joyce, James. 1992. Ulysses: annotated students'edition. Harmondsworth: Penguin Books.

Kern, Stephen. 2003. The Culture of Time and Space, 1880-1919. Harvard University Press.

Lowe, F. James. 2009. "Circean Aerodynamics". Texas Studies in Literature and Language, 5/.41: 476-493.

Mahon, Peter. 2009. Joyce: A Guide for the Perplexed. New York: Continuum International Publishing Group.

Nabokov, Vladimir. 2002. Lectures on Literature. Mariner Books.

Stenudd, Stefan. 2006. “Aristotle's Poetics”. Aristotle. Accessed May 5, 2017. www.stenudd. com/aristotle/aristotle-poetics.htm>.

Wales, Katie. 1992. The Language of James Joyce. New York: St. Martin's Press.

Джойс, Джеймс. 2013. Улисс [Joyce, James. 2013. Ulysses] (перевод Сергея Хоружого) [transl. Sergei Khorouji]. Москва: Издательство Иностранка. 